$10: 988$

<原 著 $>$

\title{
血中胆汁酸の肝疾患における臨床的意義と 赤血球膜に及ぼす影響
}

\author{
日野一成*
}

要 旨: 各種肝疾患247例につき，空腹時の血中総胆汁酸值 (F-TBA) 及び cholylglycine 值 (F-

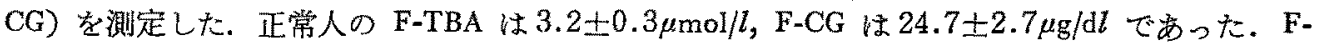
TBA，F-CG 共に肝障害が強くなるほど高値を示し，F-CG が F-TBA より $(\mathrm{p}<0.05)$ と鋭敏で あった. $300 \mathrm{mg}$ UDCA 経口負荷試験で，正常人の負荷後最高血中胆汗酸值は M-TBA $20 \mu \mathrm{mol}$ / $l$ 以下， M-CG $50 \mu \mathrm{g} / \mathrm{d} l$ 以下であった. F-TBA，F-CG 共に正常な軽度肝障害でも， M-TBA， M-CG は高值を示し，特に M-TBA は M-CG 上り（p<0.05）と鋭敏であった。肝硬変症では M-TBA が70 $\mu \mathrm{mol} / l, M-C G ~ か 3300 \mu \mathrm{g} / \mathrm{d} l$ 以上を示すが，慢性肝炎では両者共にそれ以下を示す

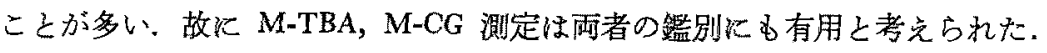

血中胆汁酸の赤血球膜への影響を検討する為, 赤血球形態の変化を走查電顕で観察した. 胆汁 酸濃度が上昇するにつれ in vivo, in vitro 共に形態変化は強くなり，一方 LCAT 活性は低下し た。このため, 血中胆汁酸は, 啭度に㐫して血中 LCAT 活性阻害作用を示し, 赤血球形態にも 変化を与克可可能性が推察された。

索引用語：血中胆汁酸 total bile acid(TBA) cholyglycine 值 (CG) 胆汁酸負荷試 験（経口）赤血球形態

\section{I. 緒 霉}

胆汁酸測定法の進歩と，その応用以よる測定の簡易 化は，胆汁酸負荷試験法の発達之共飞，血中䏣汁酸測 定を，日常的かつ，鋭敏な肝機能検査法へと怿展させ

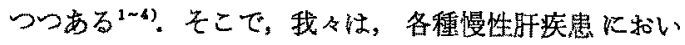
$\tau$, 空腹時と, 外因性胆汁酸負荷時飞, 血中総胆汁酸值 (total bile acid : TBA) 々, 末梢血中一次胆汁酸の大き な部分を占め, 肝でのクリアランス率の高い cholyglycine 值 (CG) を瀷し，一船肝機能検查との比较子含 めて，その有用性を模討した。

我々は，慢性肝疾患や閉塞性黄疾時に，赤血球膜脂質 飞変化が見られ，赤血球浸透压抵抗が変化することを既

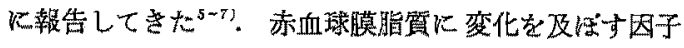

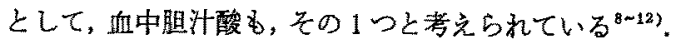
そこで我々は，慢性肝疾患と閉塞性黄疸定例の血液，拉

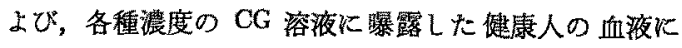

* 川崎医科大学消化器内科

<受付日57年4月5日>
ついて，その赤血球の形態変化を観察し，さらに，赤血

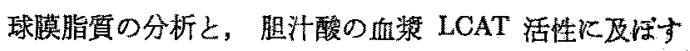
影䜾について榆討し，興味ある結果を得たので報告す る.

\section{II. 対 象}

正常対照群として当院入院患者の内，䀒疾患を有し ない15蔵から78藏までの60例 (男女，各30例)を選び， 疾患群として，急性肝炎 (acute hepatitis: AH) 13例, 慢性肝焱 (chronic hepatitis : CH) 109例, 肝硬变症 (Li= ver cirrhosis : LC) 95例, 肝癌 (Liver cancer : LCa) 17例, 閉塞性黄庭 (obstructive jaundice: Obj) 13例の 計247例孝対象とした。急性肝炎恃臨床像, 肝機能検查 成綪家総合して部断し, 急性期 (acute hepatitis florid: AHF) 6 例, 回復期 (acute hepatitis convalescent: AHC) 7 例飞分讨大，慢性肝炎は109例中95例（87\%) 飞所生模を行ない，肝機能検査值も考鹰火入れ，非活 動型 (chronic inactive hepatitis: CIH) 55例, 活動型 (chronic active hepatitis：CAH) 54例に分類した. 肝 硬変95例は腹棇鏡および，䀒生検，臨床所見により診断 
ᄂ，非代償性 (liver cirrhosis de compensted : LCD) 49 例と，代償性 (liver cirrhosis compensated : LCC) 46例 飞分類した 肝癌 (LCa) 17例は, 剖飡, 血管造影, CT, 超音波等により診断した。閉塞性黄疸 (Obj) 13例

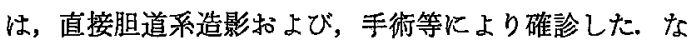
お，経口胆汁酸負荷試験については，上記症例中60例を 対象とした.

\section{III. 方 法 \\ 1. 空腹時血中胆汁酸值の測定}

空腹時血中胆汁酸測定 (Fasting-TBA : F-TBA, FastingCG : F-CG) は早朝空腹時飞 1 回採血 Lた.

1） TBA の測定 : 酳素蛍光法による Neo. Sterognost$3 \alpha$ Kit (Nyegaard \& CO. AS. OSLO) を用いた，すな わら，反応汇誤差を生じる酵素等を加熱によって失活さ せた血清に，䤃素 $3 \alpha$ 八イドロキシステロイドデヒドロ ダナーゼを作用させ，レザズリンニジつ亦ラーゼ系の 共存のもとに生じたレゾルフィンの蛍光を，励起波長 $565 \mathrm{~nm}$, 蛍光波長 $580 \mathrm{~nm}$ で測定する.

2）CG の测定：RIA 法による Dinabot 製 RIA kit を用いた，測定原理は血清試料て ${ }^{125}$ Iでラベルした CG， 扣よび CG 汶対する抗体るつ家鬼血清を加えて，一定 時間反応後，ポリエチレングリコールを加えて遠心分離 し，沈湟カウントを求め，試料の結合率を計算し，標準 曲線より濃度を求あるるのである。

\section{2. 経口胆汁酸負荷試験 (Loading test)}

外因性胆汁酸負荷試験住 ursodeoxycholic acid (UDCA) $300 \mathrm{mg}$ を早朝空腹時飞経口投与し，負荷前拈上び負荷 後30分毎に120分後まで採血し，各々について，TBA と CG を，前記の方法に従って測定した.

\section{3. 走查電韻による赤血球形悲の観察}

唕床例では，正常人，CAH，LCD，括よび Obj 例に つき，各々の赤血球形態を钼察した。また胆汁酸の赤血 球形態に扣上ぼす影響を見るため， in vitroでの検討 も行なった。すなわち，早朝空腹時に一パリン採血した Ht 約 $50 \%$ の健康人の 全血を1cc ずつ試験管に分取し, 各濃度の CG 溶液を各1 ccずつ加え，最終血浆中 CG 濃 度が，各々，活活 $0,100 ， 500 ， 4000 \mu \mathrm{g} / \mathrm{dl}$ となる Ht 約 $25 \%$ の赤血球浮遊液, 各 $2 \mathrm{cc}$ 作製し， $37^{\circ} \mathrm{C} て ゙ 6$ 時間 ンキュべートした後，走查電顕て観察した。なお，CG はグリュール酸ナトリウム塩（結晶） $99 \%$ (半井化学) を使用し，溶解液としてグルュース $300 \mathrm{mg} / \mathrm{d} l$ を含んた 生理的食塩水を用い，いずれの浮遊液も $\mathrm{pH} 7.4,310 \pm$ 5mOsm Kなるよう調整した。
1）走査電顕試料作製法：早朝空腹時にへパリン採血 した血液 1 滴をカバーグラスにのせ，2 分間放置後，余 分の血液をる紙て吸引し，まず1\%グルタールアルデヒ ドで，続いて1\%オスミウム酸で固定し， $\mathrm{pH} 7.4 ， 310$ $\pm 5 \mathrm{mOsm}, 0.1 \mathrm{M}$ リン酸緩衡夜で洗浄した後, 上昇系ア ルコール上酢酸イソフミルで脱水し，臨界点乾燥させ， $\mathrm{Au}-\mathrm{Pb}$ 蒸着して，走查電子䫓徽鏡（HHS-2R，日立）で 検鏡した。

\section{4. 赤血球膜脂質の分析}

前記，各 $\mathrm{CG}$ 濃度て $37^{\circ} \mathrm{C} ， 6$ 時間後の赤血球浮遊液中 の赤血球について分析した．分析は，既に報告した方法 に従って行なっだ、すすなわら，Rose らの方法によって 得られた試料を Iatroscan TH-10 TLC analyser (Iatron 社製）を用いて分析した。赤血球膜脂質は，展開先端上 り, FC (free cholesterol), PE (phosphatidyl ethanolamine), PS (phosphatidyl serine), PC (phosphatidyl choline), SM (sphyngomyelin) の順に分類される.

5. 血提レシチンコレステロールアシルトランスフェ ラーゼ (LCAT) 活性の測定

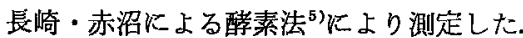
IV. 結 果

\section{1. 臨床的検討}

1) 肝突患炕梳る F-TBA， F-CG 值

Table 1 に示すように, 正常人60例 の F-TBA は 10 $\mu \mathrm{mol} / l(\mu \mathrm{M})$ 以下であった. AHF では高值をとるが， AHC では TBA は低下した。 CIH，LCC は中等度の異 常にとどまるが，CAH，LCD は中〜高度の異常を示ず． LCa, Obj では幅広い分布を示した. 正常人50例の F-CG は $50 \mu \mathrm{g} / \mathrm{d} l$ 以下であった. 各種肝胆道系疾患では F-TBA と極めて良く似た分布をしている．F-TBA および F-CG は，いずれも正常值と疾患群では0.1\%以内の危険率で 有意差を認めた。

2） F-TBA, F-CG と他の肝機能検查との相関

Table $2 k$ F-TBA，F-CG と他の肝機能検查との相 関を示した。 F-TBA，F-CG は共K GOT，GPT，BIL， LCAT，HDL-C と0.1\%以内の危険率で有意の相関を示 し, PPT と coil planet centrifuge 法による溶血終末点 (HEP) とは $5 \%$ 以内の危䧍率で相関した.

\section{3）胆汁酸負荷試験}

Fig. 1 は慢性肝疾患に打ける負荷後最高血中総胆汁 酸値 (Maximum-TBA：M-TBA) の分布を示寸. 正常 例では M-TBA は20 $\mu \mathrm{M}$ をこえない，肝実質障害が強 くなるほど M-TBA は高值をとった。 
Table 1. Serum F-TBA, F-CG, M-TBA, and M-CG levels in various liver diseases.

\begin{tabular}{l|c|c|c|c}
\hline \multirow{2}{*}{} & \multicolumn{2}{|c|}{ Fasting } & \multicolumn{2}{c}{ Loading } \\
\cline { 2 - 5 } & TBA $(\mu \mathrm{mol} / l)$ & CG $(\mu \mathrm{g} / \mathrm{d} l)$ & $\mathrm{M}-\mathrm{TBA}$ & $\mathrm{M}-\mathrm{CG}$ \\
\hline Normal & $3.2 \pm 0.3$ & $24.7 \pm 2.7$ & $14.3 \pm 1.5$ & $20.3 \pm 3.2$ \\
AHF & $89.8 \pm 35.5^{* * *}$ & $4828.2 \pm 2025.1^{* * *}$ & - & - \\
AHC & $9.6 \pm 2.1^{* * *}$ & $53.3 \pm 3.5^{* * *}$ & - & - \\
CIH & $14.6 \pm 1.4^{* * *}$ & $112.0 \pm 20.9^{* * *}$ & $43.2 \pm 3.9^{* * *}$ & $65.2 \pm 12.2^{* *}$ \\
CAH & $64.4 \pm 13.4^{* * *}$ & $912.6 \pm 245.8^{* * *}$ & $62.2 \pm 11.8^{* * *}$ & $250.3 \pm 110.0^{* * *}$ \\
LCC & $27.9 \pm 4.8^{* * *}$ & $326.1 \pm 77.2^{* * *}$ & $134.0 \pm 18.3^{* * *}$ & $1078.0 \pm 320.2^{* * *}$ \\
LCD & $64.0 \pm 8.0^{* * *}$ & $554.5 \pm 48.3^{* * *}$ & $147.5 \pm 21.5^{* * *}$ & $1050.0 \pm 123.5^{* * *}$ \\
Lca & $37.0 \pm 10.3^{* * *}$ & $523.6 \pm 207.5^{* * *}$ & $91.0 \pm 18.6^{* * *}$ & $606.0 \pm 236.8^{* * *}$ \\
Obj & $71.4 \pm 19.0^{* * *}$ & $1171.6 \pm 405.4^{* * *}$ & - & - \\
\hline \multicolumn{2}{c}{$* \mathrm{p}<0.05, * * \mathrm{p}<0.01}$, & $* * * \mathrm{p}<0.001$ & & Mean \pm SEM
\end{tabular}

Table 2. Correlation between F-TBA, F-CG and other liver function tests.

\begin{tabular}{l|c|c|c|c}
\hline \multirow{2}{*}{} & \multicolumn{2}{|c|}{ F- TBA $(\mathrm{n}=200)$} & \multicolumn{2}{c}{ F-CG $(\mathrm{n}=200)$} \\
\cline { 2 - 5 } & $r$ & $\mathrm{p}$ & $r$ & $\mathrm{p}$ \\
\hline GOT & 0.52 & $<0.001$ & 0.72 & $<0.001$ \\
GPT & 0.53 & $<0.001$ & 0.76 & $<0.001$ \\
ALP & 0.1 & $\mathrm{n} . \mathrm{s}$ & 0.07 & $\mathrm{n.s}$ \\
BIL & 0.5 & $<0.001$ & 0.44 & $<0.001$ \\
R $_{15}$ ICG & 0.75 & $<0.001$ & 0.2 & $<0.01$ \\
LCAT & -0.43 & $<0.001$ & -0.34 & $<0.001$ \\
HDL -C & -0.35 & $<0.001$ & -0.46 & $<0.001$ \\
HEP & -0.17 & $<0.05$ & -0.16 & $<0.05$ \\
ALB & -0.11 & $\mathrm{n} . \mathrm{s}$ & -0.12 & $\mathrm{n} . \mathrm{s}$ \\
PPT & 0.36 & $<0.001$ & 0.15 & $<0.05$ \\
\hline
\end{tabular}

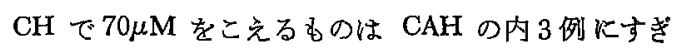
ない.一方，LC に拈いては LCD は全例70 $\mu \mathrm{M}$ 以上の

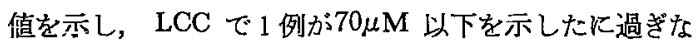
い. 従って M-TBA 値は $70 \mu \mathrm{M}$ を境として CH と LC の鑑別に有用であると考党られる.

Fig. 2 性各疾患に括り万負荷後最高血中 CG 值 (MCG）の分布を示す. 正常例では M-CG は50 $\mu \mathrm{g} / \mathrm{d} l$ をこ えない。疾患群では M-TBA と同栐の傾向を示し, CH では 1 例を除き $300 \mu \mathrm{g} / \mathrm{d} l$ 以下であり，LC では 1 例のみ $300 \mu \mathrm{g} / \mathrm{d} l$ 以下を示したにすぎない，従って M-CG では $300 \mu \mathrm{g} / \mathrm{d} l$ を境にして $\mathrm{CH}$ と LC の鑑別が可能と思われ 万.

4）慢性肝疾患に和ける䏣汁酸と他検查の異常発見率

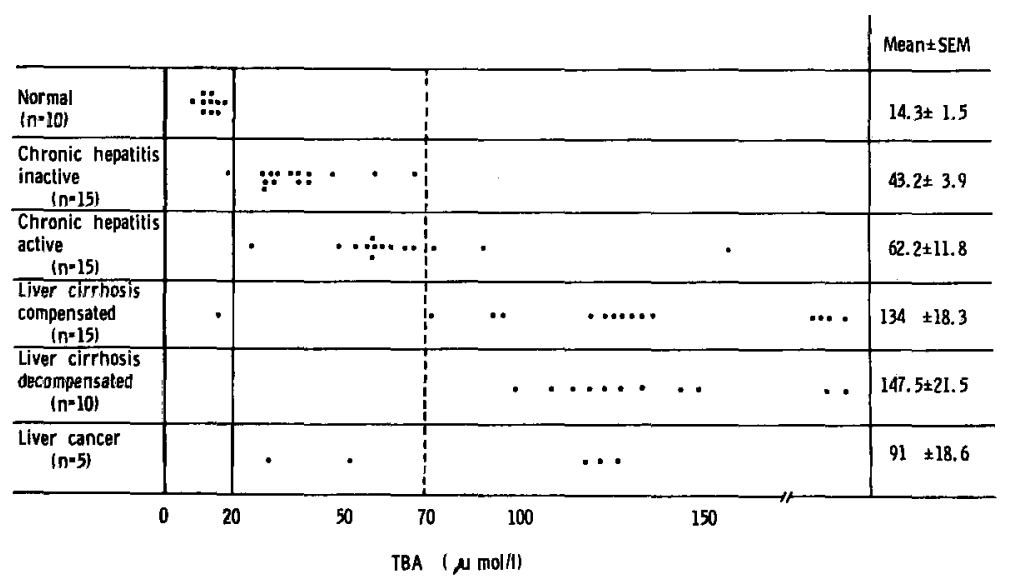

Fig. 1 Distribution of M-TBA in various liver diseases on oral UDCA Ioading. 


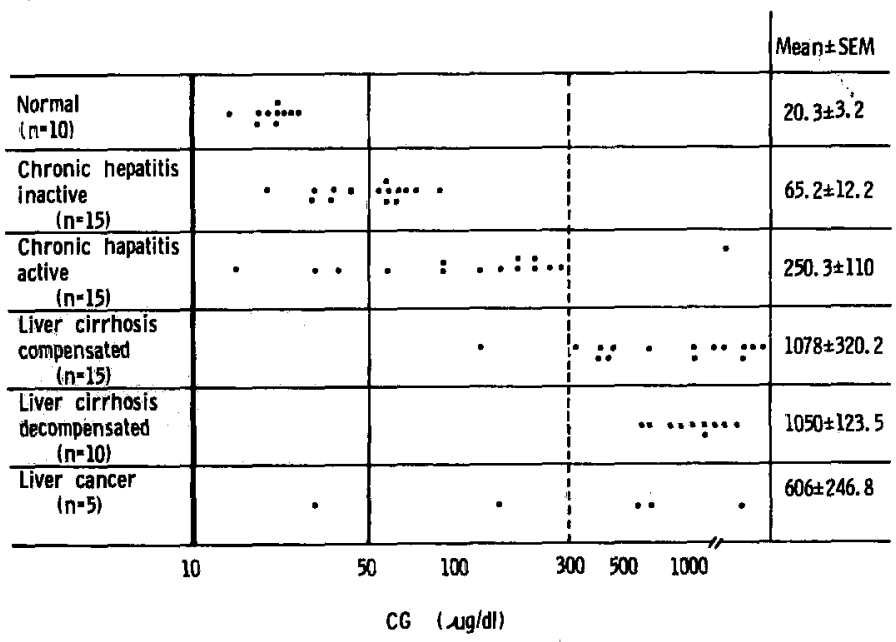

Fig. 2 Distribution of $\mathrm{M}$-CG in various liver diseases on oral UDCA loading.

\section{の此較}

Table 3 は慢性肝疾患における，空腹時の各検查の異 常発見率を示す．全体的には F-TBA，F-CG 共にトラ ンスアミナーゼと 同等の 鋭敏ざであるが F-CG の方が

Table 3. Abnormality rate of serum bile acid and other liver function tests on fasting.

\begin{tabular}{l|cccccc}
\hline & CIH & CAH & LCC & LCD & LCa & Obj \\
& $\mathrm{n}=49$ & $\mathrm{n}=54$ & $\mathrm{n}=35$ & $\mathrm{n}=35$ & $\mathrm{n}=17$ & $\mathrm{n}=10$ \\
\hline F-TBA & $61 \%$ & $83 \%$ & $85 \%$ & $91 \%$ & $76 \%$ & $80 \%$ \\
F.CG & 65 & 87 & 100 & 100 & 94 & 80 \\
GOT & 65 & 85 & 94 & 97 & 100 & 70 \\
GPT & 73 & 91 & 74 & 71 & 94 & 50 \\
BIL & 24 & 54 & 40 & 80 & 65 & 90 \\
R 15 ICG & 27 & 65 & 100 & 100 & 100 & 30 \\
LCAT & 16 & 52 & 74 & 91 & 76 & 70 \\
HEP & 55 & 61 & 74 & 80 & 59 & 90 \\
\hline
\end{tabular}

F-TBA より，やや高い発見率を示した. Table 4 は負 荷時の各検査の異常発見率を示す．全体的には，各検査

Table 4. Abnormality rate of serum bile acid and other liver function tests on oral UDCA loading.

\begin{tabular}{l|ccccc}
\hline & CIH & CAH & LCC & LCD & LCa \\
& $\mathrm{n}=15$ & $\mathrm{n}=15$ & $\mathrm{n}=15$ & $\mathrm{n}=10$ & $\mathrm{n}=5$ \\
\hline M-TBA & $93 \%$ & $100 \%$ & $93 \%$ & $100 \%$ & $100 \%$ \\
M-CG & 60 & 80 & 100 & 100 & 80 \\
F.TBA & 53 & 87 & 87 & 83 & 80 \\
F-CG & 60 & 93 & 100 & 100 & 80 \\
GOT & 60 & 80 & 100 & 100 & 100 \\
GPT & 67 & 87 & 80 & 80 & 100 \\
BIL & 7 & 33 & 53 & 100 & 20 \\
R 15 ICG & 27 & 47 & 100 & 100 & 100 \\
LCAT & 27 & 33 & 73 & 93 & 60 \\
HEP & 40 & 60 & 80 & 93 & 100 \\
\hline
\end{tabular}

Table 5. Comparison of abnormality rate of serum bile acid levels between fasting and oral UDCA loading.

\begin{tabular}{|l|rrrr|rrrrr|}
\hline & \multicolumn{4}{|c}{ Fasting } & \multicolumn{4}{c|}{ Oral UDCA loading } \\
\cline { 2 - 9 } & NO & TBA & CG & P & NO & M-TBA & M.CG & P \\
\hline CIH & 49 & $61 \%$ & $65 \%$ & n.s & 15 & $93 \%$ & $60 \%$ & $<0.05$ \\
CAH & 54 & 83 & 87 & n.s & 15 & 100 & 80 & n.s \\
LCC & 35 & 85 & 100 & $<0.05$ & 15 & 93 & 100 & n.s \\
LCD & 35 & 91 & 100 & n.s & 10 & 100 & 100 & n.s \\
LCa & 17 & 76 & 94 & n.s & 5 & 100 & 80 & n.s \\
\hline Total & 190 & 79 & 87 & $<0: 05$ & 60 & 97 & 83 & $<0.05$ \\
\hline
\end{tabular}




$$
14: 992
$$

肝

䑏

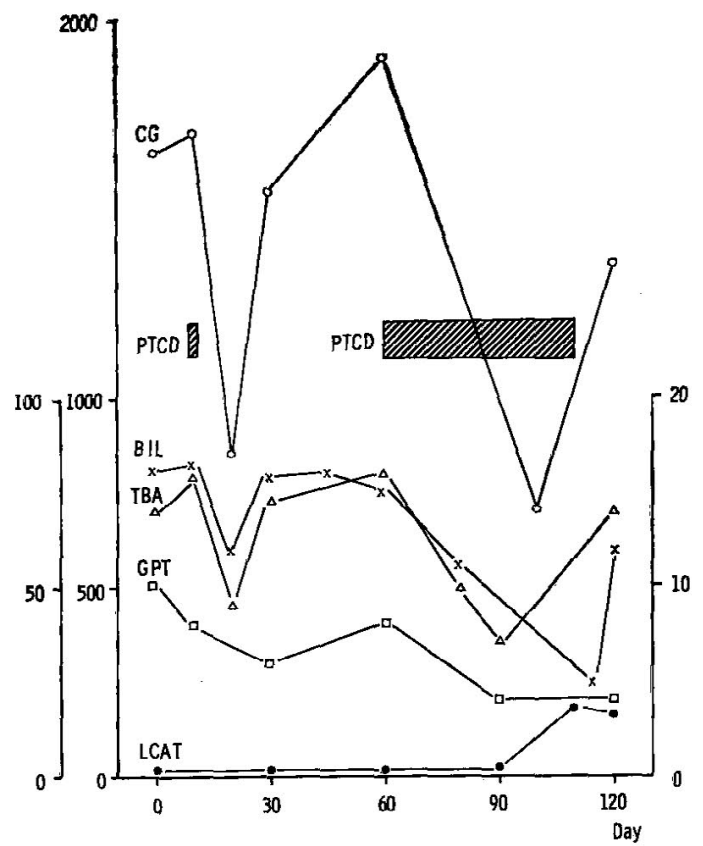

Fig. 3 Serial changes of TBA, CG and other biochemical tests in a patient with obstructive jaundice.

共に空腹時と同様の異常発見率であるが，特に CIH に おいて M-TBA が93\%と高率を示した点が注目される。

5) 慢性肝疾患に打ける血中胆汁酸 (TBA, CG) 測定 の比較

Table 5 は空腹時と負荷時の TBA と CG の各矤患に 和ける異常発見率と両者間の有意差検定の結果を示す。 F-TBA そ F-CG については，いずれの疾患も異常発見 率は CG が高率である。F-TBA と F-GG 注 LCCを除 き，発見率江有意美性見られなかったが，慢性肝疾患全 体では F-CG の方が $5 \%$ 以内の危険率で F-TBA 上り 有意汇鋭敏であった.

これとは逆に M-TBA と M-CG については M-TBA が，5\%以内の危険率で M-CG 上り高い異常発見率を 示乙圭。

6）各稹旰疾患に打ける TBA，CG の経時的変化

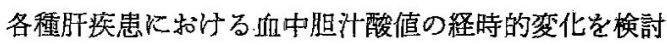
した. 図火は示していないが，AH では回復期に向かう につれて, 胆汁酸值は低下した. しかし， $\mathrm{CH}$ ○Cで は,トランスアミナーぜ等の変化とは必ずしる相関せ ず，一定の傾向を示さなかった。

Obj 例飞拈ける PTCD 後の胆汁酸值の変動を Fig. 3

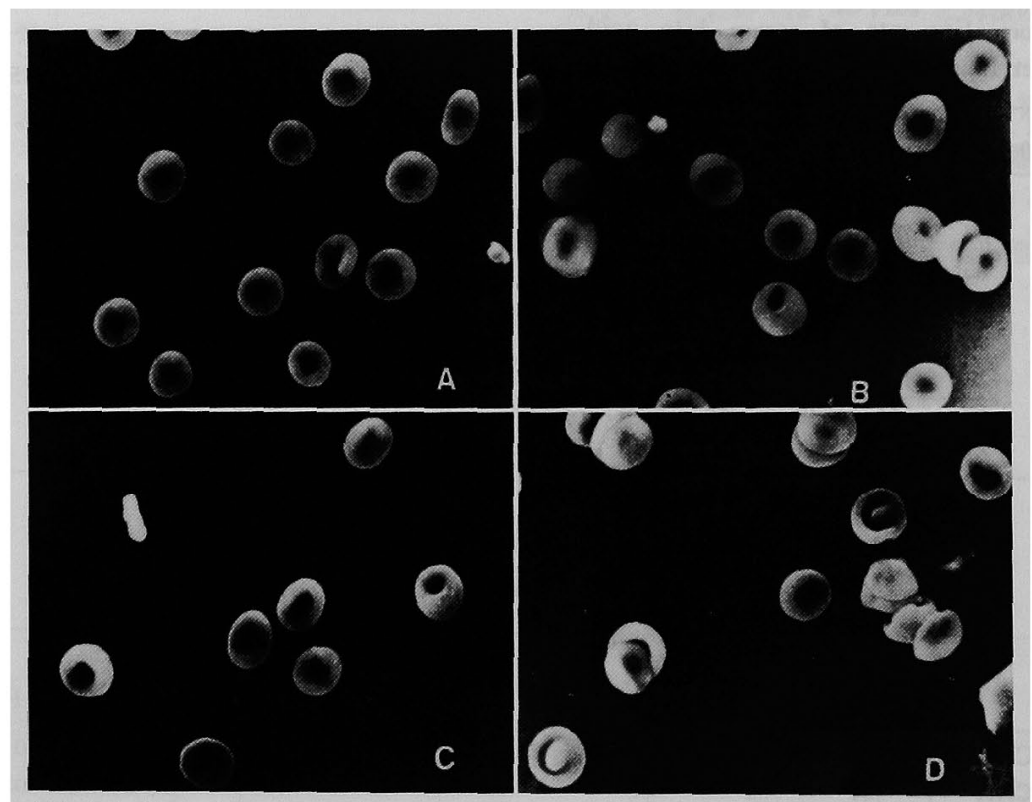

Fig. 4 Scanning electron micrographs of erythrocytes of patients with liver diseases.
A : normal
B : liver cirrhosis (CG $200 \mu \mathrm{g} / \mathrm{d} l$ )
$\mathrm{C}:$ chronic active hepatitis (CG $800 \mu \mathrm{g} / \mathrm{d} l$ )
$\mathrm{D}$ : obstructive jaundice (CG $1600 \mu \mathrm{g} / \mathrm{d} l$ ) 


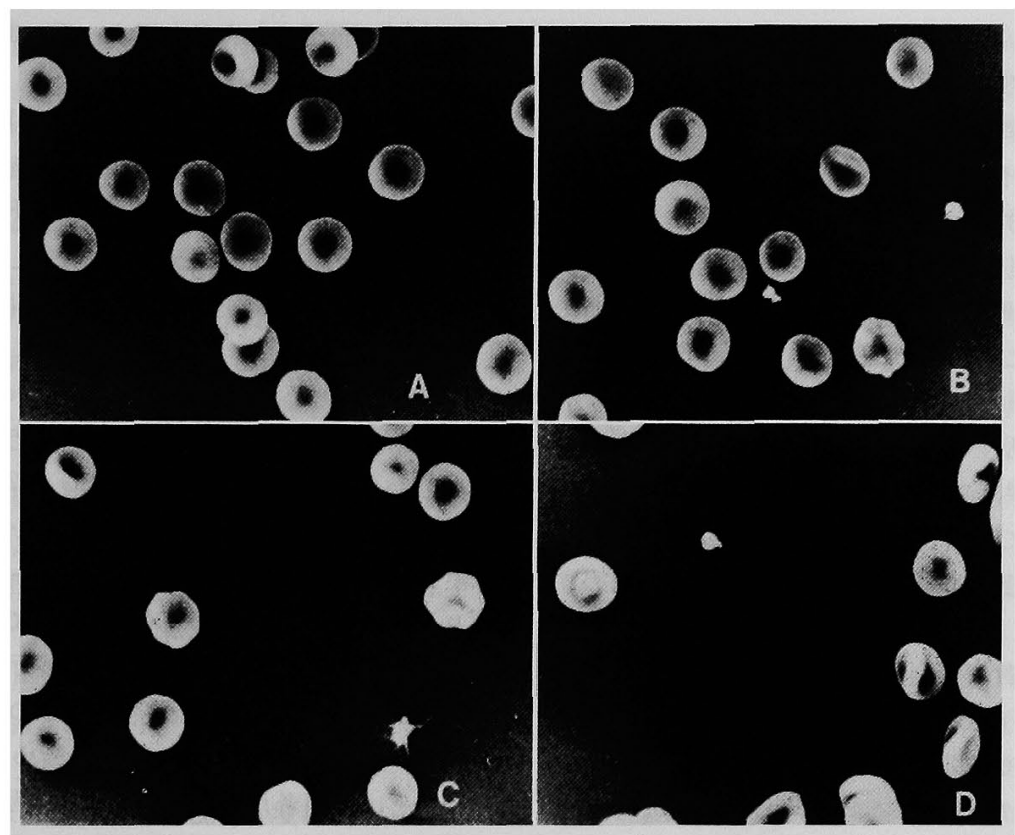

Fig. 5 Scanning electron micrographs of erythrocytes incubated with various concentration of CG in vitro.
A : CG $0 \mu \mathrm{g} / \mathrm{d} l$
B : CG $100 \mu \mathrm{g} / \mathrm{d} l$
$\mathrm{C}: \mathrm{CG} 500 \mu \mathrm{g} / \mathrm{d} l$
$\mathrm{D}: \mathrm{CG} 4000 \mu \mathrm{g} / \mathrm{d} l$

に示す. 症例は60蔵男性で, 䀒門部癌である. 1 回目 の PTCD 後, BIL の低下に従い, TBA, CG 共に急速 な低下を認めた，先の後，ドレナージチューブ拔去後， TBA，CG 共に堌加を示したが， 2 回月の PTCD 実施 後，両者は再び，寸みやかに低下した。この図で明らか なように，TBA と CG は BIL の低下と比べて，ょり 速い改善を示した. LCAT 活性は，やや遈れて 回復し てきた。

\section{2. 胆汁酸の赤血球膜に及ぼす影響}

1）走㚗電顕による赤血球形態変化の推察

Fig. 4 は肝疾患患者の赤血球形態を示す. A は健康 人例で, 大きさ, 形の均一な discocyte を示している. B は CG 濃度 $200 \mu \mathrm{g} / \mathrm{d} l$ の LCC 例である. 赤血球の大き さ，形が不均一となり， stomatocyte 様の赤血球が出現 し, 一部, codocyte も認められる. Cは CG 濃度 800 $\mu \mathrm{g} / \mathrm{d} l$ の $\mathrm{CAH}$ の例である. 赤血球の大きさ, 形は不均 一で, stomatocyte が出現している. Dは CG 濃度1,600 $\mu \mathrm{g} / \mathrm{d} l$ の Obj 例であるが target cell の出現が見られ た.

Fig. 5 は各種濃度の CG 溶夜で， $37^{\circ} \mathrm{C}, 6$ 時間イン キニペートした健康人赤血球の変化を示している，Aは
CGを加えていない赤血球で, 形のきれいな discocyte である. Bは CG 濃度 $100 \mu \mathrm{g} / \mathrm{d} l$ の例で，大きさは，や や不均一となり, echinocyte I が散見される. Cは CG 澧度 $500 \mu \mathrm{g} / \mathrm{d} l$ の例である.ややり，大きさ，形は不均 一であり, echinocyte IK加宇てII 認められる. Dは CG 溲度 $4,000 \mu \mathrm{g} / \mathrm{d} l$ の例である. target cell が認めら れる. このように，赤血球形態は CG 濃度が上暴する につれ, in vivo, in vitro 共に変形著明となる傾向を示

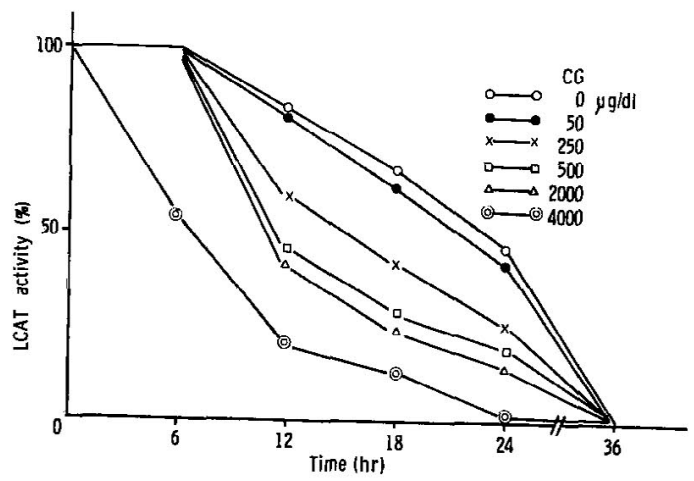

Fig. 6 Inhibition of the serum LCAT activity by the various concentration of added CG. 
$16: 994$

肝

t.

2）胆汁酸によるLCAT 活性の変化

赤血球形態観察に用いたと同様の CG 溶液を濃度0〜

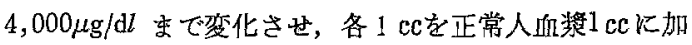
え, 計 $2 \mathrm{cc} と し, 37^{\circ} \mathrm{C} て ゙ 36$ 時間インキュべートし，その 間，6時間每に血頨中 LCAT 活性を测定 したものが Fig. 6 である，6時間後では， $2,000 \mu \mathrm{g} / \mathrm{d} l$ までの濃度 では LCAT 活性に变化はないが，4,000 $\mathrm{g} / \mathrm{d} l$ では活性 は50\%程度に低下した。ささらに時間の経過と共に，すべ ての例で LCAT 活性の低下が見られる．ただ，胆汁酸 の LCAT 阻害效果は, 正常人にみられる CG 䀼度 0 $50 \mu \mathrm{g} / \mathrm{d} l$ と比較して，250〜2,000 $\mu \mathrm{g} / \mathrm{d} l$ では，より強く 見られ，より高嚙度 $4,000 \mu \mathrm{g} / \mathrm{d} l$ ではさらに強く阻害さ れた.

\section{3）赤血球膜脂質の変化}

前述した如く，正常人血液に CGを100 4,000 $\mathrm{g} / \mathrm{d} l$ まで加党， $37^{\circ} \mathrm{C} ， 6$ 時間インキュベート後, 各々の赤血 球膜脂質を分析した。その結果， Table 6 に示すよう に, 総脂質 (total lipids), PE, PS, SM K使変化を認 めなかったが PC は CG 濃度が上年するにつれて增加 乙, 赤血球外膜と内膜の比である $(\mathrm{SM}+\mathrm{PC}) /(\mathrm{PE}+\mathrm{PS})$ も，CG 濃度の上昇に従って增加可分傾向を示した。

Table 6. Lipid composition of erythrocyte-membrane in various concentration of $\mathrm{CG}$.

\begin{tabular}{r|c|c|c|c|c|c|c}
\hline $\begin{array}{c}\mathrm{CG} \\
(\mu \mathrm{g} / \mathrm{d} l)\end{array}$ & $\begin{array}{c}\text { total lipids } \\
(\mathrm{mg} / \mathrm{gHb})\end{array}$ & $\begin{array}{c}\mathrm{FC} \\
(\mathscr{O})\end{array}$ & $\begin{array}{c}\mathrm{PE} \\
(\mathscr{O})\end{array}$ & $\begin{array}{c}\mathrm{PS} \\
(\mathscr{\%})\end{array}$ & $\begin{array}{c}\mathrm{PC} \\
(\mathscr{O})\end{array}$ & $\begin{array}{c}\mathrm{SM} \\
(\mathscr{O})\end{array}$ & $\begin{array}{c}(\mathrm{PC}+\mathrm{SM}) / \\
(\mathrm{PE}+\mathrm{PS})\end{array}$ \\
\hline 0 & 11.22 & 50.3 & 14.9 & 6.4 & 13.8 & 14.6 & 1.09 \\
100 & 11.72 & 48.5 & 14.6 & 6.4 & 14.9 & 15.0 & 1.17 \\
500 & 11.34 & 49.5 & 13.6 & 8.2 & 15.0 & 13.8 & 1.08 \\
4000 & 11.67 & 47.8 & 14.3 & 7.1 & 15.2 & 15.5 & 1.21 \\
\hline
\end{tabular}

\section{v. 考察}

肝細胞で、ンレステロールから合成ざれる胆汁酸は， それ自身の持つ細胞毒性のため，閉鎖的な腸肝循環の中 に扎し込められて，大循環系とは接せず，健康人では， 末梢血中胆汁酸は極めて微量である.しかし，各種朋胆 道系疾患では，肝細胞障害や shunt 等の存在のため, 肝での胆斗酸処理能力が低下し，末梢血中に，胆汁酸が 増量することが以前から知られていたそのため，血中 胆汁酸を測定して，肝機能検查に利用しようといら努力 は続けられていたが, 従来の方法では, 抽出, 分雇等に 問題があり, 臨床への応用に難点があった.しかし，近 年に至り，酵溸蛍光法"1)，RIA 法"2などの技術が 確立さ れて, 測定が容易になったことと，各種の胆汁酸負荷試
23 巻 9 号 (1982)

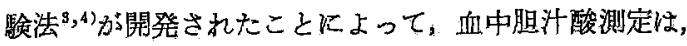
その臨床的意義を高めつつある。

既に我今は，䀒疾患134例火つき，F-TBA と F-CGの 比較検討の結果, 肝障害が強い程，両者共に高值を示す こと，さらに CIH では F-CG が F-TBA より鋭敏に 肝障害を反咉するといら結果を報告している ${ }^{13)}$. 今回, 我々はさらに症例をらやし，各種肝胆道系疾患247例に つき検討を加光た。

Table 1 に示すように, 正常例での F-TBA は3.2士 $0.3 \mu \mathrm{M}$ で, 正常值 $10 \mu \mathrm{M}$ 以下という従来の報告(‘)一

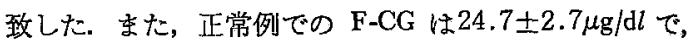
これも正常値 $50 \mu \mathrm{g} / \mathrm{d} l$ 以下といら報告 ${ }^{14)}$ と一致 してい る。疾患群に持いては，F-TBA，F-CG 共に高值をと り, 特に AHF, CAH, LCD, Obj で高值を示し, 肝障 害が強くなる程，高值をとる傾向を示した，次にF-TBA および F-CG と他の肝機能検查との相関では GOT, GPT，BIL，LCAT，HDL-C 等と極めて良〉相関L，こ のことは，耐者共に，肝実質障害の程度，あるいは肝予 備能を反映していると考えられる，しかしながら，空腹 時胆汁酸測定のみでは, 胆汁酸濃度は疾患の間で重複 が多く, 特に CIH のような軽度の肝障害では F-TBA, F-CG 共に異常発見率は53〜65\%と，トランスアミナー ビの65〜73\%に比較して，鋭敏度でやや劣っている，そ こで，経口胆汁酸負荷試験を行なった結果，全体では， M-TBA は $\mathrm{p}<0.05$ て M-CG より鋭敏であり，特に CIH で M-TBA D異常発見率注93\%と高い検出率老 示した.これは，同時に測定した他の肝機能検查の異常 発見率が67\%以下であったことと比べてる，従来の肝機 能検查で発見の難しい軽度の肝障害に特いても，M-TBA の測定が極めて有用であることを示唆している。

さて，大菅ら“は M-TBA 70 肝资と肝硬変の鑑別が可能であるらと報告しているが， 我々あ同様の結果を得た。一方，M-CG Kついての報告 は従来見られないが，我々は，300 $\mu \mathrm{g} / \mathrm{d} l$ を境にして， 両者の鑑別が可能であららといら結果を得た.

以上のように，空腹封血中胆汁酸測定は，全般的な胵 障害のスクリーニングとして有用であり，F-CG の方が F-TBA ょり，全体で $\mathrm{p}<0.05$ と有意に 鋭敏であった。 さらに，負荷試験を行ならことにより，軽度の肝障害の 発見が可能となり，慢性肝炎と肝硬変の鑑㣍炕むある程 度有用であると考えられた。

肝胆道系疾患に颃いて，赤血球が echinocyte，spherocyte target cell 等の形態変化を示し, 赤桖球浸透压 
抵抗が增加する現象は以前から知られており，赤血球膜 脂䓄の变化が，これらの現象に深くかかわっていること が報告されてきだー8),15 17). Cooper ら $ら^{8)}$ は, 閉塞性黄疸 時に赤血球膜にコレステロールが蓄積するが，これは， 血中胆汁酸の増加の結果であると報告し, その後さらに Cooper ${ }^{15)}$, 安藤 ${ }^{16)}$, 吉田 ${ }^{17}$, 山本 $\check{5}^{6,7)}$ は, 赤血球膜脂 質の内で，特に $\mathrm{FC}$ とC の変化が赤血球形態牤よび 赤血球唚透圧抵抗に影響を及法すことを報告している. この現象について, Glomoset $5^{9 /}$, Murphy $5^{10)}$, Cooper ら ${ }^{11}$ は，胆汁酸が LCAT 活性を阻害するため FC が増加し，その結果，赤血球浸透生抵抗が低下すると推 測乙, 北島 $5^{12}$ 无血浆中胆汁酸濃度と最終溶血浸透圧 (HEP)の間に相関を認め，上記の説を支持している.

一方, Jones ら ${ }^{18)}$ は CG $0.1 \mathrm{mM}$ 以下では, 胆汁酸に LCAT 活性阻害作用はないとし，Calandra $5^{19}$ ，安藤

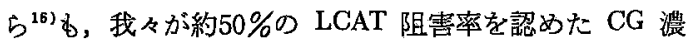
度に近い0.16mM 周辺の濃度では，いずれの胆汁酸る in vitro での LCAT 阻害効果は20\%程度に過ぎず，血 浆中の胆汁酸濃度と HEP の間にも相関は認められな かったとして，胆汁酸の LCAT 阻害因子としての存在 を疑問視している。

このように，胆计酸の LCAT 阻害効果については必 ずしも一定の結論が得られていないところで，我々は 前述したよ5に, 胆汁酸濃度は LCAT 活性 $(\mathrm{p}<0.001)$ 及び HEP $(p<0.05)$ と良好な相関を示すことを認め ている.この事実を，さらに分析するため，正常血浆に 各種濃度の CG を添加し, 血中 LCAT 活性が, との程 度阻害されるかを調べた，その結果， $37^{\circ} \mathrm{C} ， 6$ 時間イン キュペーション後で，CG 濃度が $4,000 \mu \mathrm{g} / \mathrm{d} l$ において 約50\%の阻害効果を認めた。 また，肝胆道系疾患で通 常見られる CG 濃度 $500 \sim 2,000 \mu \mathrm{g} / \mathrm{d} l$ では LCAT 阻害 は，汇とんど見られないが，12時間以上のインキュベー ション゙ては $250 \mathrm{\mu g} / \mathrm{d} l$ 以上の CG は，明らかに LCAT 活 性阻害効果が認められた。

赤血球の走查電顕による形態観察においては，肝胆道 系疾患例では，LCAT 活性が30\% 40\%の低下を示す。 CG 濃度 $200 \sim 800 \mu \mathrm{g} / \mathrm{d} l$ の例では, stomatocyte が出現 L，70\% 90\%の LCAT 活性低下を示す. CG 1,600 $\mathrm{g}$ / $\mathrm{d} l$ の例では target cell を認めた.

以上のように，䏣汁酸は LCAT に対して阻害效果を 及ぼす可能性が示唆された。 また，胆汁酸濃度が高く， LCAT 活性低下が大きければ大きいはと，赤血球形態 に強い変化を来す㑯向が楒められた.
しかし, in vitro の㬰験では, 赤血球形態は臨床例と 同様に変化を示し，その程度は，CG 濃度と一定の相関 が見られるものの，LCAT 活性は，臨床例における活と 明らかな低下を示さなかった。

このことに関して，Billington ら 赤血球膜脂質に直接的な影響を及仿し，赤血球が echinocytic 又は, stomatocytic な変化を起こす可能性を報 告している.

従って，胆汁酸の赤血球形態に及活す影響は，胆汁酸 の LCAT 活性阻害作用のみならず，胆汁酸自身の赤血 球膜に対する直接的な影響の可能性る考慮ざれねばなら ないであるら。

\section{VI. 結 論}

各種肝胆道系疾患247例を 対象として，空腹時括よび 胆汁酸負荷時に 血中胆汁酸濃度 (TBA，CG) 学測定 $し$ た.さらに, 肝胆道系疾患患者の血液と, 各種濃度の CG 溶液に曝露した健康人血液について，胆汁酸濃度と 血中 LCAT 活性, 赤血球形態特よび赤血球膜脂質の関 係を検討し，以下の結諭を得た.

(1) 空腹時血中胆汁酸湘定としては，F-CG の方が F-TBA より鋭敏であり，肝障害のスクリーニングに有 用である。

(2) 胆汁酸負荷試験は軽度の肝障害の発見に有用であ り，M-TBA の方が M-CG より鋭敏に肝機能を反映す る.さらに M-TBA，M-CG の測定は慢性肝炎と肝硬变 症の鑑別にも，ある程度，有用である.

(3) Ifin中胆汁酸は in vivo, in vitro 共に，その濃度 に応して血中 LCAT 活性を゙阻害し, 赤血球膜脂質と赤 盂球形態変化に，影響を及湾す可能性が推定された。

本論文の要旨は、日本消化器病学会中国四国第36回地 方会において発表した。

なお，稿を釉るにあたり，御校閲睗わっだ平野筧教授 に深詂いたします。重た，本諭文の作成执よび研究に直 接御指導を戴きました山本晋一郎助教授に竧意を表する とともに，赤血球膜脂質分析について御協力いたたい た，本院救急部，武元良整講師に感謝いたします。

\section{文献}

1) 真重文子, 柳沢悦子, 大菅俊明：血中胆汁酸の 簡易微量定量法, 臨床化学 $4: 312-318,1976$

2) Simmons WJ, Korman MG, Go VLW, et al: Radioimmunoassay of conjugated cholyl bile acids in serum. Gastroenterology $65: 705-711$, 
1973

3）因城明子：肝疾患に抽けるursodeoxycholic acid 経口負荷試験 の 臨床的意䇅. 肝葴 20：369一. 375,1979

4）田中直見，大菅俊明；血清胆汁酸. 日本臨床， 38 ，春季増刊号，209-220，1980

5) 山本晋一郎, 山下佐知子, 大橋勝彦, 他 : 閉塞 性黄渲における赤血球浸透比抵抗の変化. 第 I 編, 各種閉塞性黄迫時の CPC 像. 日消誌 76 : $2415-2422, \quad 1979$

6) 山本晋一郎, 武元良整, 山下佐知子, 他：閉塞 性黄疾に抢ける赤血球浸透圧抵抗の変化, 第 II 編，閉塞性黄疸時の赤血球膜脂質の変化, 日消 誌 $76: 2424-2430,1979$

7) 山本亚一郎，武元良整，山下佐知子他：肝疾患 に特汀る赤血球浸透汪抵抗と赤血球膜脂質（速 報). 日消誌 $78: 122 ， 1981$

8) Cooper RA, Jandl JH: Bile salts and cholest erol in the pathogenesis of target cells in obstructive jaundice. J Clin Invest 47: $809-822$, 1968

9) Glomoset JA: Physiological role of lecithin cholesterol acyltransferase. Am J Clin Nutr, 23: $1129-1135,1970$

10) Murphy JR: Erythrocyte metabolism. VI. Cellshape and the location in erythrocyte membrane. J Lab Clin Med 65: 756_-774, 1965

11) Cooper RA: Influence of membrane lipid. Alteration on red cell function. In: Red Cell Membrane, Jamieson GA and Greenwalt TJ, editors. Philadelphia, 1969, Lippincott, pp. 339

12) Kitazima K, Shibata S: Coil planet centrifugation and its application to the observation of altered membrane properties of erythrocytes in hepatobiliary disorders. J Lab Clin Med 85: $855-864,1975$

13）日野一成，山本留一郎，山下侮知子他：肝疾患 に和惊る血中胆汁酸 (TBA，CG）測定の比較 検討一空腹時 和上び UDCA 経口負荷時の相遑 (速報)，日消誌 $78 ： 2197 ， 1981$

14）大营俊明，田中直見，真重文子：血清胆汁酸， 最新医学 $35: 2425-2430,1980$

15) Cooper RA, Diloy-Puray $M$, Lando $P$, et al: An analysis of lipoproteins, bile acids, and red cell membranes associated with target cells and spur cells in patients with liver disease. J Clin Invest $51: 3182-3192,1972$

16) 安藤 喬, 吉田 洋, 寺倉俊勝, 他 : 肝, 胆道 疾患に打ける赤血球浸透圧抵抗，日消誌 $74 ：$ $329-339,1977$

17) 吉田 洋, 小橧和夫, 寺倉俊勝, 他 : 胆汁与 っ滞における赤血球浸透圧抵抗増強のメカニズ 々之臨床的意義. 日消誌 $77: 591$ - 601，1980

18) Jones DP, Sosa FR, Shartsis J, et al: Serum cholesterol esterifying and cholesteryl ester hydrolyzing activities in liver diseases: Relationships to cholesterol, bilirubin, and bile salt concentrations. J Clin Invest 50: 259-265, 1971

19) Calandra S, Martin MJ, McIntyre N: Plasma lecithin: cholesterol acyltransferase activity in liver disease. Europ J Clin Invest 1: 352-360, 1971

20) Billington D, Coleman R: Effects of bile salts on human erythrocytes, plasma membrane vesiculation, phospholipid solubilization and their possible relationships to bile secretion. Biochim Biophys Acta 509: 33—47, 1978 


\title{
Clinical significance of serum bile acid in liver diseases and its effect on erythrocyte membrane
}

\begin{abstract}
Kazunari HINo*
Serum levels of fasting total bile acid (F-TBA) and cholylglycine (F-CG) were examined in 247 cases with hepatobiliary diseases. Normal fasting level was $3.2 \pm 0.3 \mu \mathrm{mol} / l$ in TBA and $24.7 \pm 2.7 \mu \mathrm{g} / \mathrm{d} l$ in CG, respectively. Both F-TBA and F-CG levels became higher according to the degree of liver disfunction and F-CG was more sensitive than F-TBA $(p<0.05)$ in detecting liver disfunction. In oral loading test of $300 \mathrm{mg}$ ursodeoxycholic acid, maximum TBA (M-TBA) was less than $200 \mu \mathrm{mol} / l$ and M.CG did not exceed $50 \mu \mathrm{g} / \mathrm{d} l$ in normal controls. Even in mild liver disease like chronic inactive hepatitis with normal F-TBA and F.CG, both M-TBA and M-CG showed abnormal results. M-TBA was more sensitive than $M-C G(p<0.05)$. In liver cirrhosis, many cases showed more than $70 \mu \mathrm{mol} / l$ of M-TBA and $300 \mu \mathrm{g} / \mathrm{d} l$ of M-CG, while in chronic hepatitis, both $M$ TBA and M-CG were less than those levels. Therefore, it could be useful in the differentiation of liver cirrhosis and chronic hepatitis to measure M-TBA and M-CG.

Scanning electron microscopic observation was done to know the morphological changes of the erythrocyte. Higher concentration of bile acid made the erythrocyte from discocyte to target cell both in vivo and in vitro. While, LCAT activity gradually decreased as the bile acid concentration became higher. It may be germane to say that bile acids inhibit LCAT activity and change the erythrocyte shape.
\end{abstract}

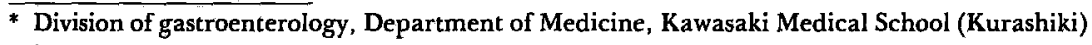

